\author{
ks. Zygfryd Glaeser ${ }^{1}$ \\ Wydział Teologiczny Uniwersytetu Opolskiego
}

\title{
W służbie jedności Kościoła. Ekumeniczny program pontyfikatu św. Jana Pawła II
}

\section{Streszczenie}

Ekumeniczny program św. Jana Pawła II cechuje nie tylko wymiar horyzontalny, urzeczywistniający się w osobistych spotkaniach, w wymianie myśli i duchowych darów. Obejmuje także wymiar wertykalny, polegający „na wspólnym i wzajemnym uznaniu naszej kondycji jako ludzi, którzy zgrzeszyli”, co - według Jana Pawła II otwiera „wewnętrzną przestrzeń, w której Chrystus jako źródło jedności Kościoła może skutecznie działać mocą swego Ducha - Parakleta" (UUS, nr 35). Nadając ekumenizmowi priorytetowy charakter w programie swojego posługiwania, Jan Paweł II zwraca szczególną uwagę na dwa elementy, które wzajemnie się warunkują. Są to: „pamięć i jej oczyszczanie oraz pojednanie”.

Słowa kluczowe: Jan Paweł II, Kościół, ekumenizm, pojednanie, dialog

1 Ks. Zygfryd Glaeser (ORCID: 0000-0002-8791-0175) - prof. dr hab., kierownik katedry Teologii Fundamentalnej, Dogmatycznej i Ekumenizmu w Instytucie Nauk Teologicznych Wydziału Teologicznego Uniwersytetu Opolskiego; członek krajowych i zagranicznych towarzystw naukowych, m.in.: Gesellschaft zum Studium des Christlichen Ostens (GSCO), St. Irenaeus Joint Orthodox-Catholic Working Group; ekspert Komisji Ewaluacji Nauki przy Ministerstwie Nauki i Szkolnictwa Wyższego; członek Komisji ds. Stosunków Polsko-Czeskich i Polsko-Słowackich PAN; uczestnik obrad Katolicko-Prawosławnej Komisji do Dialogu Teologicznego (Boltimore 2000); konsultor Rady Episkopatu Polski ds. Ekumenizmu; delegat Konferencji Episkopatu Polski w międzynarodowym projekcie „Pojednanie w Europie Środkowo-Wschodniej" (współprzewodniczący projektu); autor i redaktor książek oraz artykułów z zakresu teologii dogmatycznej i ekumenicznej oraz z zakresu tematyki historyczno-integracyjnej, publikowanych w różnych językach (najistotniejsze: Wjednym Duchujeden Kościót. Pneumatologiczna eklezjologia Nikosa A. Nissiotisa, Opole 1996; Ku eklezjologii „Kościołów siostrzanych”. Studium ekumeniczne, Opole 2000; U źródeł własnej tożsamości, Opole 2003; Kamień Śląski. Szmaragd opolskiej ziemi, Opole 2004; Z. Glaeser, Eucharystia w dialogu. Wokół bilateralnych uzgodnień doktrynalnych Kościoła prawosławnego na temat Eucharystii, Opole 2007; Ślaskie Sebastianeum. Walory Kamienia Ślaskiego jako centrum hydroterapii według księdza Sebastiana Kneippa, Kamień Śląski 2014; Ekumenizm w nauczaniu papieży po Soborze Watykańskim II, Kamień Śląski-Opole 2017). 


\section{Summary}

In the Service of the Church's Unity. Ecumenical Program of the Pontificate of St. John Paul II

The ecumenical program of St. John Paul II is characterized not only by the horizontal dimension, which is carried in personal meetings, in the exchange of thoughts and spiritual gifts. It also includes a vertical dimension, consisting in "mutual and reciprocal recognition of our condition as people who have sinned," which, according to John Paul II - opens "an internal space in which Christ as the source of the Church's unity can effectively act by the power of the Spirit - the Paraclete" (UUS, no. 35). By giving ecumenism priority in the program of its ministry, John Paul II pays special attention to two elements. They are: "memory and its purification and reconciliation."

Keywords: John Paul II, Church, ecumenism, reconciliation, dialogue

Jednym z istotnych rysów pontyfikatu św. Jana Pawła II jest jego ekumeniczne zorientowanie ${ }^{2}$. „Papież z dalekiego kraju”, nazajutrz po wyborze na Stolicę Piotrową, w orędziu wygłoszonym w Kaplicy Sykstyńskiej na zakończenie konklawe, wyraził programową deklarację:

Nie godzi się nam [...] zapomnieć o Braciach należących do innych Kościołów i do innych Wspólnot chrześcijańskich. Sprawa ekumenizmu jest tak ważna i wymaga tak wielkiej roztropności, że w tej chwili nie wolno nam o niej milczeć. Ileż to razy rozmyślaliśmy wspólnie o ostatniej woli Chrystusa, który prosił Ojca o dar jedności dla swoich uczniów (por. J 17, 21-23). Któż nie pamięta, z jakim naciskiem św. Paweł mówił o „jedności duchowej”, dzięki której uczniowie Chrystusa będą mieli „tę samą miłość i wspólnego ducha, pragnąc tylko jednego" (por. Flp 2, 2)?3

W deklaracji programowej, wyraźnie wynikającej z własnych przemyśleń papieża, odkrywamy motyw bezzwłocznego i bezwarunkowego włączenia się następcy św. Piotra w dzieło ekumenii. Jest nim zgorszenie, którego powodem są podziały istniejące wśród chrześcijan oraz ekumeniczna nadzieja płynąca z radykalnego odczytania wezwania Chrystusa,

2 Szerzej na ten temat zob. Z. Glaeser, Ekumenizm w nauczaniu papieży po Soborze Watykańskim II, Kamień Śląski-Opole 2017, s. 75-114, 329-844.

3 Zob. Z. Glaeser, Wprowadzenie, w: Pontyfikat ekumenicznej nadziei. Z Janem Pawłem II na drogach ekumenizmu, red. Z. Glaeser, Opole 2008, s. 7-8. 
„aby stanowili jedno” (J 17, 21). Finalnym celem ekumenicznych dążeń jest, zdaniem papieża, „doskonała jedność”, którą należy urzeczywistniać4. W uroczystości inaugurującej nowy pontyfikat (22.10.1978) udział wzięli liczni przedstawiciele Kościołów i Wspólnot chrześcijańskich spoza Kościoła rzymskokatolickiego. Wówczas to nowy papież wezwał wszystkich chrześcijan i ludzi dobrej woli do otwarcia się na Chrystusa:

Nie lękajcie się. Otwórzcie, otwórzcie na oścież drzwi Chrystusowi! Jego zbawczej władzy otwórzcie granice państw, systemów ekonomicznych, systemów politycznych, kierunków cywilizacyjnych. Nie lękajcie się! Chrystus wie, „co jest w człowieku". On jeden .

Tamto przesłanie okazało się wręcz programowe dla pontyfikatu św. Jana Pawła II. Stało zapowiedzią otwartości nowego papieża na dialog ekumeniczny i na dialog ze światem. Nie dziwi więc fakt, że Jan Paweł II nieustannie wzywał chrześcijan do angażowania się na rzecz uskuteczniania pełnej widzialnej jedności w Chrystusowym Kościele. Za Soborem Watykańskim II wyrażał swój sprzeciw wobec podziałów istniejących w chrześcijaństwie, gdyż - jak podkreślał - każdy podział w Kościele przeciwny jest woli Chrystusa ${ }^{6}$, a w konsekwencji skierowany jest zawsze przeciwko Kościołowi. Stąd ekumenizm postrzegał jako „imperatyw chrześcijańskiego sumienia oświeconego wiarą i kierowanego miłością" . Stale przypominał więc prawdę o tym, że to przecież Chrystus wzywa swoich uczniów do jedności. Dlatego wierzący w Niego, zjednoczeni w naśladowaniu męczenników, nie mogą pozostać podzieleni ${ }^{8}$, gdyż „grzech [...] podziału jest bardzo ciężki” . Podział wśród chrześcijan Jan Paweł II nazywa godnym pożałowania stanem, który dla wielu stanowi

4 Z. Glaeser, Ekumenizm w nauczaniu papieży po Soborze Watykańskim II, dz. cyt., s. 77.
5 G. Weigel, Świadek nadziei, Kraków 2000, s. 335.
6 Por. Sobór Watykański II, Dekret o ekumenizmie „Unitatis redintegratio”, nr 1, w: Sobó Watykański II, Konstytucje. Dekrety. Deklaracje, Poznań 2002, s. 193-208 (dalej: DE).

7 Jan Paweł II, Encyklika Ut unum sint, nr 8, AAS 87 (1995), s. 921-982. Tekst pol. zob. OsRomPol 16 (1995) nr 6, s. 4-31 (dalej: UUS).

8 Por. Jan Paweł II, List apostolski Tertio millennio adveniente, nr 37, AAS 87 (1995), s. 5-45. Tekst. pol. zob. OsRomPol 15 (1994) nr 12, s. 4-22 (dalej: TMA).

9 Jan Paweł II, List apostolski Orientale lumen, nr 17, AAS 87 (1995), s. 745-774. Tekst. pol. zob. OsRomPol 16 (1995) nr 6, s. 32-44 (dalej: OL). 
przyczynę wahań, a nawet zgors zenia. Chrześcijańskim obowiązkiem sumienia jest więc opowiadania się po stronie jedności i wspólnoty, a tym samym sprzeciwianie się podziałom, jakie nieustannie zagrażają Kościołowi. Chodzi przecież w konsekwencji o otwarcie się na dar jednoczącej obecności Ducha Świętego ${ }^{10}$. Jan Paweł II wzywał więc chrześcijan do rachunku sumienia, aby w trzecie tysiąclecie wchodzili bardziej pojednani i „bliżsi przezwyciężenia podziałów powstałych w drugim tysiącleciu”"11.

Pontyfikat św. Jana Pawła II naznaczony jest wieloma inicjatywami ekumenicznymi. W pierwszej w dziejach Kościoła encyklice w całości poświęconej ekumenizmowi wyraźnie potwierdził, że zaangażowanie Kościoła rzymskokatolickiego w ekumenizm jest nieodwracalne. Co więcej, ekumenizm uznał za jedyną właściwą drogę Kościoła, która nie ma nic wspólnego z przemijającą modą. Szczególną wartość ekumenizmu dostrzegał we wspólnej modlitwie oraz we wspólnym poszukiwaniu i odkrywaniu prawdy.

\section{Istotne elementy ekumenicznego programu św. Jana Pawła II}

Święty Jana Pawła II konsekwentnie i z przekonaniem realizował ekumeniczny program, który jasno nakreślił u początków swojego pontyfikatu. Stałym punktem jego apostolskich wizyt były spotkania ekumeniczne, o które osobiście zabiegał. Niemalże we wszystkich jego dokumentach odkrywamy wypowiedzi o charakterze ekumenicznym ${ }^{12}$. Przełomowe znaczenie w tej materii ma pierwsza w dziejach Kościoła encyklika Ut unum sint - „Aby stanowili jedno” w całości poświęcona ekumenizmowi. Papież przypomina w niej, że „Kościół katolicki z nadzieją podejmuje dzieło ekumeniczne jako imperatyw chrześcijańskiego sumienia oświeconego wiarą i kierowanego miłością" ${ }^{13}$. Wspomnieć również należy wiele innych dokumentów o wymiarze ekumenicznym listy apostolskie: Tertio millennio adveniente (U progu trzeciego tysiącle-

10 Z. Glaeser, Ekumenizm w nauczaniu papieży po Soborze Watykańskim II, dz. cyt., s. 78.

11 TMA, nr 34.

12 Zob. K. Starczewski, Ekumenizm w nauczaniu papieży. Od Jana XXIII do Benedykta XVI, Kielce 2018, s. 153-280.

13 UUS, nr 8. 
cia, 1994), Orientale lumen (O chrześcijańskim Wschodzie, 1995) oraz List z okazji 500. rocznicy urodzin Marcina Lutra (1983).

Bardzo ważne przesłanie ekumeniczne św. Jan Paweł II zamieścił w liście Novo millennio ineunte ${ }^{14}$ opublikowanym na zakończenie obchodów Wielkiego Jubileuszu Roku 2000. Pisze w nim o „smutnym dziedzictwie przeszłości”, które podzieliło wyznawców Chrystusa. Wzywa więc do nawrócenia serc i do wspólnej modlitwy, które doprowadzą do niezbędnego oczyszczenia pamięci historycznej ${ }^{15}$.

Ważnym elementem ekumenicznego programu pontyfikatu św. Jana Pawła II były jego wizyty m.in. w siedzibie patriarchy Konstantynopola, w katedrze Canterbury, w Światowej Radzie Kościołów, w rzymskim zborze ewangelickim i w synagodze rzymskiej. Papież doprowadził także do oficjalnego rozpoczęcia dialogu między Kościołem rzymskokatolickim i Kościołem prawosławnym oraz do podpisania przełomowej dla stosunków katolicko-luterańskich Wspólnej deklaracji w sprawie nauki o usprawiedliwieniu ${ }^{16}$.

W swojej pierwszej encyklice Redemptor hominis św. Jan Paweł II usilnie wzywał chrześcijan, by rzetelnie, wytrwale, pokornie i odważnie szukali dróg ku pełnej jedności w Chrystusowym Kościele, wypełniając w ten sposób testament Chrystusa ${ }^{17}$. Szczegółowo swój pogląd skonkretyzował w encyklice Ut unum sint:

Ta jedność, którą Pan dał swemu Kościołowi i którą pragnie ogarnąć wszystkich, nie jest czymś mało istotnym, ale stanowi centralny element Jego dzieła. Nie jest też

14 Jan Paweł II, List apostolski Novo millennio ineunte, AAS 93 (2001), s. 266-309. Tekst pol.: http://www.opoka.org.pl/biblioteka/W/WP/jan_pawel_ii/listy/novo_millenio_06012001. html (12.05.2017).

15 UUS, nr 2. Ważnym wydarzeniem w procesie oczyszczania pamięci była „Eucharystia pojednania”, która miała miejsce w pierwszą niedzielę Wielkiego Postu 12.03.2000 r. w Bazylice św. Piotra w Rzymie. Teksty zob. Celebrazione Eucaristica. Prima domenica di Quaresima. „Giornata del perdono", Vaticano 2000, s. 94. Por także J.B. Metz, Czy Kościót potrzebuje nowej reformacji? Odpowiedź katolika, Poznań-Warszawa 1970 s. 272-279 (Concilium. Międzynarodowy Przegląd Teologiczny, 1/5); J. Ratzinger, Kościół wspólnota, Lublin 1993, s. 92-100.

16 Tekst zob. https://papiez.wiara.pl/doc/477995.Wspolna-deklaracja-w-sprawie-nauki-o-usprawiedliwieniu (12.12.2019).

17 Jan Paweł II, Encyklika Redemptor hominis, nr 6, AAS 71 (1971), s. 257-324. Tekst. pol.: Encykliki Ojca Świętego Jana Pawła II, t. 2, Kraków 1996, s. 5-76. 
drugorzędnym przymiotem wspólnoty Jego uczniów, lecz należy do jej najgłębszej istoty. Bóg pragnie Kościoła, ponieważ pragnie jedności i właśnie w jedności wyraża się cała głębia Jego agape. [...] Wierzyć w Chrystusa znaczy pragnąć jedności; pragnąć jedności znaczy pragnąć Kościoła; pragnąć Kościoła, znaczy pragnąć komunii łaski, która odpowiada zamysłowi Ojca, powziętemu przed wszystkimi wiekami. Taki właśnie jest sens modlitwy Chrystusa: ut unum sint ${ }^{18}$.

W adhortacji Ecclesia in Europa św. Jan Paweł II pisze, że jedność chrześcijan jest „niezbędnym warunkiem większej wiarygodności w ewangelizacji”"19. Dlatego jedność i realizacja chrześcijańskiej misji są nierozłączne.

Święty Jan Paweł II jest przekonany co do tego, że „dążenie ekumeniczne wywiera wpływ na życie wewnętrzne chrześcijan, którzy powinni pozwolić, aby ono ich kształtowało”20, gdyż „ekumenizm [...] nie jest tylko jakimś «dodatkiem» czy uzupełnieniem tradycyjnego działania Kościoła. Przeciwnie, należy on w sposób organiczny do całości jego życia i działania, i w konsekwencji, winien tę całość przenikać jak owoc zdrowego i kwitnącego drzewa, które osiąga pełnię życia"21.

Zachęcał więc chrześcijan, by nie zniechęcać się trudnościami, jakie spotykają w pełnieniu ekumenicznej posługi jednania. Podczas wizyty ad limina rosyjskich biskupów w 2001 roku powiedział:

Nie trzeba tracić ducha w obliczu trudności, a nawet niepowodzeń, jakie są na drodze ekumenizmu, lecz z pomocą modlitwy ze wszystkich sił należy kontynuować budowanie pełnej jedności pomiędzy uczniami Chrystusa ${ }^{22}$.

Ważnym elementem ekumenicznego programu św. Jana Pawła II było nawiązywanie i rozwijanie osobistych kontaktów z głowami Kościołów i Wspólnot chrześcijańskich. Podczas swoich apostolskich podróży spotykał się więc z kościelnymi i religijnymi liderami. Przestrzegał przed

18 UUS, nr 9.

19 Jan Paweł II, Adhortacja apostolska Ecclesia in Europa, nr 30, AAS 95 (2003), s. 649-719. Tekst pol.: http://www.opoka.org.pl/biblioteka/W/WP/jan_pawel_ii/adhortacje/europa_28062003.html (12.05.2017).

20 UUS, nr 15.

21 UUS, nr 20.

22 „L'Osservatore Romano” (11.02.2001), 6. 
tym, by w ekumenii nie zredukować do socjologii, bądź też do suchej doktrynalnej debaty. Wskazywał więc, za Soborem Watykańskim II, na „nawrócenie serca”, „świętość życia” i na „modlitwę”, jako najistotniejsze czynniki ekumenicznego zaangażowania, nazywając je „duszą ekumenizmu"23. Wzywał do tego, aby ekumeniczna otwartość odzwierciedlała się w praktyce codziennego życia chrześcijan. Wielokrotnie dawał wyraz przekonaniu, że jedność Kościoła jest darem Ducha Świętego danym i zadanym wszystkim chrześcijanom ${ }^{24}$. Wspólne odkrywanie ewangelijnej drogi zbawienia i pojednania jest - jego zdaniem - niczym innym jak powrotem do pierwotnego zamysłu Chrystusa: „aby stanowili jedno" (J 17, 21). Zachęcał więc do podejmowania dialogu, wychodząc z założenia, że to właśnie dzięki dialogowi chrześcijanie uczą się „razem”, jako siostry i bracia w wierze, wzrastać w misterium Chrystusa i Jego Kościoła. Dialog stwarza również możliwość poznawania siebie nawzajem oraz wspólnego wnikania w głębię prawd chrześcijańskiego Objawienia. Nie chodzi tu jednak tylko o czysto teoretyczne poznanie, ale o takie, które wciąga życiowo w obręb poznawanej rzeczywistości, otwiera nowe perspektywy, uwrażliwia na określony sposób postępowania i kształtowania życia. Staje się więc szansą spotkania w wierze, odnajdywania, odbudowywania i uskuteczniania siostrzano-braterskich więzów eklezjalnych, a w konsekwencji wspólnego dawania świadectwa Ewangelii ${ }^{25}$. „Postawa «dialogiczna» odpowiada naturze osoby i jej godności”26. Dialog ekumeniczny stanowi „narzędzie” na drodze uskuteczniania pełnej komunii Kościołów. Służy pogłębianiu istotowej jednomyślności w wyznawaniu wiary wewnątrz jednego widzialnego Kościoła. Określa też płaszczyznę „uprawnionej różnorodności” w wyrażaniu tej samej wiary. Stanowi istotny element

${ }_{23}$ Zob. UUS, nr 21; DE, nr 7-8. Zob. także Z. Glaeser, Wjednym Duchu jeden Kościół, Opole 1996, s. 194.

${ }_{24}$ Zob. T.J. Chlebowski, Jedność - zadany dar Ducha Świętego, „Biuletyn Ekumeniczny” 131/132 (2004) 3/4, s. 58-66.

25 Zob. Z. Glaeser, Droga dialogu - droga pojednania, w: Pojednanie narodów i Kościołów. Materiały sympozjum poświęconego problematyce II Europejskiego Zgromadzenia Ekumenicznego - Graz ‘97, red. P. Jaskóła, Opole 1997, s. 119-120.

${ }^{26}$ UUS, nr 28. 
na jedynej drodze do samospełnienia człowieka: zarówno poszczególnych osób, jak też każdej wspólnoty. Chociaż w pojęciu „dialog” zdaje się wysuwać moment poznawczy (dia-logos), każdy dialog ma również wymiar całościowy, egzystencjalny. Angażuje cały ludzki podmiot; dialog między wspólnotami angażuje w sposób szczególny podmiotowość każdej z nich. [...] Nie jest tylko wymianą myśli, ale zawsze w jakiś sposób wymianą darów ${ }^{27}$.

Zdecydowanie przekracza więc granice konwersacji. Ma bowiem prowadzić do prawdziwie osobowego spotkania. Św. Jan Paweł II inicjował więc liczne międzykościelne dialogi doktrynalne i pastoralne. Wspierał także te, które już były prowadzone. Podkreślał, że to dialog jest ważnym czynnikiem warunkującym autentyczność inicjatyw o charakterze ekumenicznym ${ }^{28}$.

Święty Jan Paweł II Autor Ut unum sint często przypominał o tym, że dialog to nie tylko przywilej i obowiązek dla wybranych. Wezwanie do dialogu dotyczy wszystkich chrześcijan i niechrześcijan, poszczególnych ludzi i Kościołów. Papież przypominał o tym, że

ekumenizm [...] nie jest jakimś tylko «dodatkiem», uzupełnieniem tradycyjnego działania Kościoła. Przeciwnie, należy on w sposób organiczny do całości jego życia i działania i w konsekwencji winien tę całość przenikać i z niej wyrastać jak owoc ze zdrowego i kwitnącego drzewa, które osiąga pełnię życia ${ }^{29}$.

Toteż „wszyscy wierni, idąc za wezwaniem Ducha Bożego, mają czynić, co jest w ich mocy, aby więzy komunii między wszystkimi chrześcijanami umacniały się i aby wzrastała współpraca uczniów Chrystusa"30.

Święty Jan Paweł II przypomina o tym, że dialogiczna wrażliwość nie ogranicza się wyłącznie do spraw doktrynalnych, ale angażuje całego człowieka: jest także „dialogiem miłości”. Dzięki bezpośrednim kontaktom

27 UUS, nr 28.

28 Por. Z. Glaeser, Zadania Kościołów w kształtowaniu europejskiej jedności, w: Pojednanie. Ekumeniczne wyzwania Grazu '97, red. Z. Glaeser, P. Jaskóła, Opole 1998, s. 54-57; Z. Glaeser, Enzyklika „Ut unum sint” als Ausdruck der Verantwortung der Römisch-katholischen Kirche für die Versöhnung unter den Christen, w: Ökumenische Verantwortung der Kirchen am Beispiel der Polens und der Schweiz, Hrsg. P. Jaskóła, Opole 1997, s. 62-66.

29 UUS, nr 20.

30 UUS, nr 101. 
na różnych szczeblach, między pasterzami oraz między członkami Kościołów bardziej wiarygodnym staje się świadectwo, jakie „wspólnie” dają oni o Bogu. Przywrócenie pełnej widzialnej wspólnoty między Kościołami wymaga więc kształtowania nowego stylu wzajemnych odniesień, opartych na szacunku i wzajemnej życzliwości. Duch konkurencji i walki wyznaniowej musi ustąpić miejsca mentalności prawdziwie ekumenicznej. Należy więc zdecydowanie odejść od odziedziczonej z przeszłości logiki zwycięstw i porażek, a opowiedzieć się za chrześcijańską logiką siostrzaności, braterstwa i wzajemnej odpowiedzialności.

Święty Jan Paweł II, choć wielką wartość przypisywał dokumentom wypracowywanym w ramach międzykościelnych dialogów doktrynalnych, a ekumenicznej modlitwie nadawał priorytetowy charakter, był przekonany co do tego, że równie ważne miejsce w budowaniu dobrych relacji między chrześcijanami i między Kościołami mają ekumeniczne gesty i praktyczne inicjatywy, będące często wyrazem szacunku jednych do drugich i potwierdzające szczerość ekumenicznych intencji i słów. W pontyfikacie św. Jana Pawła II można wskazać wiele inicjatyw, mających wręcz historyczne i przełomowe znaczenie dla ekumenii ${ }^{31}$. Oto niektóre $\mathrm{z}$ nich ${ }^{32}$ : wizyta w zborze ewangelicko-luterańskim w Rzymie (11.12.1983); wizyta w Rzymie ekumenicznych patriarchów Konstantynopola: Dimitriosa I (1987), Bartłomieja I (1995, 2002 i dwa razy w 2004); wizyta w Rzymie arcybiskupów Canterbury: Roberta Runcie (1982, 1989), George'a Careya $(1996,1997,2000)$ i Rowana Williamsa (2003); modlitwa o pokój w Asyżu (1986, 2002); wspieranie inicjatyw Europejskich Zgromadzeń Ekumenicznych (Bazylea - 1989, Graz - 1997); prośby o napisanie tekstu nabożeństwa Drogi Krzyżowej odprawianej w Wielki Piątek w rzymskim Koloseum (patriarcha Bartłomiej - 1994, Olivier Clément - 1998); wizyta w Rzymie katolikosów Ormiańskiego Kościoła Apostolskiego Karekina I (1996) i Karekina II (2000); wizyta w Rzymie ormiańskiego katolikosa Cylicji Arama I Keshishiana (1997);

31 Zob. Z. Kijas, Ekumenizm, w: Jan Paweł II. Encyklopedia dialogu i ekumenizmu, red. E. Sakowicz, Radom 2006, s. 163-199.

32 Zob. S. Pawłowski, Ekumeniczne dokumenty i inicjatywy Jana Pawła II oraz ich istotne przesłanie, w: Pontyfikat ekumenicznej nadziei. Z Janem Pawłem II na drogach ekumenizmu, red. Z. Glaeser, Opole 2008, s. 173-178. 
sympozjum Prymat następcy Piotra (Rzym, 2-4.12.1996) - akta ukazały się w formie książki w 1998 roku; międzynarodowe sympozjum na temat Jana Husa; próba jego „rehabilitacji” (Rzym, 1999). Pragnienie zbadania tej sprawy wyraził Jan Paweł II już podczas pielgrzymki do Czechosłowacji (1990); wspólne otwarcie „Drzwi Świętych” w Bazylice św. Pawła przez Jana Pawła II, prymasa anglikańskiego i metropolitę z Patriarchatu Ekumenicznego Konstantynopola, w obecności przedstawicieli Kościołów i Wspólnot kościelnych z całego świata (18.01.2000); przekazanie greckiej wspólnocie prawosławnej rzymskiego kościoła św. Teodora na Palatynie (30.11.2000); dokument Międzynarodowej Komisji Teologicznej Pamięć i pojednanie. Kościół i winy przeszłości (2000); przekazanie Kościołowi ormiańskiemu relikwii św. Grzegorza Oświeciciela (2001); wyrażone podczas pielgrzymki do Grecji (2001) przeprosiny papieża za grzechy katolików wobec prawosławnych, uczynione zwłaszcza z racji „zdobycia Konstantynopola” przez krzyżowców w 1204 roku; wizyta w Rzymie prawosławnego patriarchy Rumunii Teoktysta (2002); przekazanie Rosyjskiej Cerkwii Prawosławnej ikony Matki Boskiej Kazańskiej (2004); przekazanie Patriarchatowi Ekumenicznemu Konstantynopola relikwii świętych Grzegorza z Nazjanzu (teologa) i Jana Chryzostoma (2004).

Wielką praktyczną „manifestacją” o charakterze ekumenicznym były uroczystości pogrzebowe Jana Pawła II (08.04.2005). Uczestniczyli w nich m.in: ekumeniczny patriarcha Konstantynopola Bartłomiej, delegacje wysokiego szczebla reprezentujące niemal wszystkie Kościoły prawosławne, zwierzchnicy Kościołów orientalnych: Karekin II, Aram I i Mar Dinkha IV, anglikański arcybiskup Canterbury Rowan Williams, delegacje Światowej Federacji Luterańskiej, Światowej Rady Metodystów, Światowego Aliansu Kościołów Reformowanych, Utrechckiej Unii Starokatolików, sekretarz generalny Światowej Rady Kościołów dr Samuel Kobia. Uczestnictwo w pogrzebie Jana Pawła II tak wielu delegacji reprezentujących różne Kościoły i środowiska chrześcijańskie świadczy o wielkim uznaniu dla ekumenicznej otwartości papieża i dla jego ekumenicznego programu. 


\section{Ekumenizm z Kościołami prawosławnymi}

Jan Paweł II z wdzięcznością podjął ekumeniczne dziedzictwo swoich poprzedników Jana XXIII, Pawła VI oraz Jana Pawła I, konsekwentnie je rozwijając i pogłębiając. W 1979 roku spotkał się w Fanarze z patriarchą Konstantynopola Dimitrosem I. Owocem spotkania było zainicjowanie teologicznego dialogu między Kościołem rzymskokatolickim i Kościołami prawosławnymi. Patriarcha ekumeniczny przybył do Rzymu z rewizytą w 1987 roku. W ten sposób zrodził się dobry zwyczaj wzajemnych odwiedzin: w Rzymie, w uroczystość Apostołów Piotra i Pawła i w Fanarze w święto Andrzeja Apostoła ${ }^{33}$.

W encyklice Ut unum sint Jan Paweł II wyróżnia dwa wydarzenia bardzo wymowne z punktu widzenia ekumenicznego, mające bardzo ważne znaczenie w ekumenicznych relacjach między Kościołem rzymskokatolickim i prawosławnymi Kościołami wschodnimi. Pierwsze, to przypadający na 1984 rok jubileusz apostołów Słowian, świętych Cyryla i Metodego, których papież, razem ze św. Benedyktem, ogłosił współpatronami Europy $^{34}$. Drugie wydarzenie to świętowanie w 1988 roku jubileuszu 1000-lecia chrztu Rusi. Wydarzenia przywołane przez Jana Pawła II stały się okazją do przypomnienia, że Kościół powinien oddychać dwoma płucami - wschodnim i zachodnim ${ }^{35}$.

Jan Paweł II odbył kilka pielgrzymek do krajów określanych jako prawosławne. Pierwszym z nich była Rumunia, kraj w ok. 80\% zamieszkany przez ludność prawosławną. Rumuński Kościół Prawosławny bardzo serdecznie przyjął papieża-Słowianina, a patriarcha Teoktyst, po Eucharystii w Bukareszcie (9.05.1999), w obecności Jana Pawła II, wyraził pragnienie, aby obydwaj hierarchowie mogli wreszcie stanąć razem przy

33 Por. S. Pawłowski, Ekumeniczne dokumenty i inicjatywy Jana Pawła II oraz ich istotne przesłanie, dz. cyt., s. 173-178.

34 Zob. UUS, nr 53-54. Zob. także Jan Paweł II, Encyklika Slavorum Apostoli, nr 27, AAS 77 (1985), s. 779-813. Tekst pol.: http://www.opoka.org.pl/biblioteka/W/WP/jan_pawel_ii/encykliki/slavorum.html (16.04.2017); Jan Paweł II, List apostolski Egregiae virtutis, AAS 73 (1981), 258-262. Tekst pol.: http://www.cyrylimetody.marianie.pl/egregiae.htm (19.05.2017).

35 Por. UUS, nr 53-54. 
jednym ołtarzu. Kolejnym „krajem prawosławnym” na drodze pielgrzymowania Jana Pawła II była Gruzja (listopad 1999 r.), a następnie Grecja (maj 2001 r.). Papież przeprosił wówczas Kościół prawosławny za IVwyprawę krzyżową, podczas której, w 1204 roku, zachodnie rycerstwo zdobyło i ograbiło Konstantynopol. Podążając śladami św. Pawła, Jan Paweł II spotkał się także z przedstawicielami Kościoła prawosławnego w Syrii.

Przełomowym momentem $\mathrm{w}$ relacjach z prawosławiem patriarchatu moskiewskiego była wizyta duszpasterska Jana Pawła II na Ukrainie (czerwiec 2001 r.), w czasie której doszło do spotkania z hierarchami Ukraińskiego Kościoła Prawosławnego Patriarchatu Moskiewskiego.

We wrześniu 2001 roku Jan Paweł II odwiedził Kazachstan i Gruzję, gdzie również spotkał się z przedstawicielami Kościoła prawosławnego. Podobnie było w 2002 roku, kiedy papież przybył do Bułgarii. Jan Paweł II spotykał się z wyznawcami prawosławia także w Polsce, czego przykładem była wspólna modlitwa papieża $\mathrm{z}$ hierarchami prawosławnymi w prawosławnej katedrze w Białymstoku.

Ważnym wydarzeniem dla Rosyjskiego Kościoła Prawosławnego były obchody 1000-lecia chrztu Rusi Kijowskiej. Z tej okazji Jan Paweł II opublikował list apostolski Euntes in mundum (1988), gdzie Kościół prawosławny określił Kościołem siostrzanym. Wyraził również konieczność rozwijania obustronnej współpracy na rzecz pojednania, gdyż obie „wielkie tradycje i obie formy kultury dopełniają się wzajemnie jakby dwa «płuca» w jednym organizmie"36.

Jan Paweł II wspierał działania obydwu Kościołów zmierzające do powołania bilateralnej komisji do dialogu teologicznego, co stało się faktem w 1980 roku. Komisja wypracowała kilka znaczących dokumentów. Jej prace należy widzieć jako żmudne przygotowanie uzgodnień doktrynalnych, które mają prowadzić do zbliżenia obydwu Kościołów.

36 Jan Paweł II, List apostolski Euntes in mundum, nr 12, AAS 80 (1988), s. 935-956. Tekst pol.: http://franciszkanska3.pl/janpawel2/nauczanie/listy-apostolskie/euntes-in-mundum-universum (12.04.2017). 


\section{Ekumenizm ze Wspólnotami ewangelickimi ${ }^{37}$}

Jan Paweł II, będąc etykiem, połączył w pewnym sensie ekumenizm z wolnością religijną. Ta oryginalna wizja ekumenizmu pozwoliła mu dostrzec wiele pól „obecności” człowieka, które miały stać się wspólną troską katolików i protestantów ${ }^{38}$. Niezwykle wymownym dokumentem Jana Pawła II, ukazującym postać Marcina Lutra oraz historyczno-kulturowe uwarunkowania jego kontestacji, był jego list skierowany do kard. Johannesa Willebrandsa (ówczesnego przewodniczącego Sekretariatu Jedności Chrześcijan) z okazji 500-lecia urodzin Marcina Lutra $(31.10 .1983)^{39}$. Papież pisał w nim o głębokiej religijności Lutra,

którą powodowany, stawiał z gorącą namiętnością pytania na temat wiecznego zbawienia. Okazało się też wyraźnie, że zerwania jedności Kościoła nie można sprowadzać ani do niezrozumienia ze strony pasterzy Kościoła katolickiego, ani też jedynie do braku zrozumienia prawdziwego katolicyzmu ze strony Lutra. [...] Nie powinniśmy ulegać pokusie, by stawać się sędziami historii, ale tylko mieć na celu lepsze zrozumienie wydarzeń, aby stać się nosicielami prawdy ${ }^{40}$.

Wkrótce po ogłoszeniu Listu z okazji pięćsetlecia urodzin Marcina Lutra Jan Paweł II wziął udział w liturgii słowa Bożego w kościele luterańskim w Rzymie (11.12.1983) ${ }^{41}$. W dniu 25 marca 1993 roku, z polecenia Jana Pawła II, Papieska Rada dla Popierania Jedności Chrześcijan ogłosiła Dyrektorium $w$ sprawie realizacji zasad $i$ norm dotyczacych ekumenizmu ${ }^{42}$. Jednak kluczowym dokumentem dla rozwoju dialogu ekumenicznego z protestantami okazała się encyklika Ut unum sint. Jan Paweł II powiązał

37 Z. Glaeser, Ekumenizm w nauczaniu papieży po Soborze Watykańskim II, dz. cyt., s. 103-107.

38 Zob. E. Sakowicz, Jan Paweł II wobec protestantów i protestantyzmu, „Egzorcysta” (2017) nr 10/62, s. 55-60.

39 Jan Paweł II, List z okazji pięćsetlecia urodzin Marcina Lutra, w: Ut unum. Dokumenty Kościoła katolickiego na temat ekumenizmu 1982-1998, red. S.C. Napiórkowski, K. Leśniewski, J. Leśniewska, Lublin 2000, s. 334-335.

40 Jan Paweł II, List z okazji pięćsetlecia urodzin Marcina Lutra, dz. cyt.

${ }^{41}$ Zob. Jan Paweł II, Wszyscy jesteśmy objęci łaską Pana naszego Jezusa Chrystusa. Przemówienie w zborze ewangelicko-luterańskim w Rzymie, w: Ut unum, dz. cyt., s. 484-485.

42 Papieska Rada dla Popierania Jedności Chrześcijan, Dyrektorium w sprawie realizacji zasad i norm dotyczacych ekumenizmu, tłum. L. Balter, „Communio” 80 (1994) nr 2, s. 3-93. Wcześniejsze Dyrektorium zostało wydane w dwóch częściach w 19671970 roku. 
w niej ekumenizm z wiarą w Jezusa Chrystusa, podkreślając, że „wierzyć w Chrystusa znaczy pragnąć jedności”43. Dnia 17 listopada 1980 r. w Moguncji na spotkaniu z Radą Kościoła Ewangelickiego Niemiec Jan Paweł II powiedział:

Pozwólcie mi na początku naszej rozmowy wypowiedzieć to, co jest dla mnie szczególnie ważne. Uczynię to, nawiązując do Listu do Rzymian, do tego tekstu, który miał dla Marcina Lutra tak wielkie znaczenie. „Ten list jest głównym dziełem Nowego Testamentu i najbardziej wymowną Ewangelią" - napisał w roku 1522. W szkole Apostoła Narodów możemy sobie uświadomić, że wszyscy potrzebujemy nawrócenia. [...] „Przestańmy więc wyrokować jedni o drugich” (Rz 14, 13). Chciejmy jednak, jedni i drudzy, uznać naszą winę ${ }^{44}$.

Początek pontyfikatu Jana Pawła II przypadł na drugą fazę dialogu luterańsko-rzymskokatolickiego w latach 1973-1984. Dialog ten miał wyraźne wsparcie papieża. Zaowocował sześcioma dokumentami: Wieczerza Pańska (Das Herrenmahl, 1978) ${ }^{45}$; Drogi do wspólnoty (Wege zur Gemeinschaft, 1980) ${ }^{46}$; Wszyscy pod jednym Chrystusem (Alle unter einem Christus) ${ }^{47}$ - dokument wydany z okazji 450. rocznicy Konfesji Augsburskiej (1980); Urząd duchowny w Kościele (Das geistliche Amt in der Kirche, 1981) ${ }^{48}$; Marcin Luter świadek Jezusa Chrystusa (Martin Luter - Zeuge Jesu Christi, 1983) ${ }^{49}$ - dokument z okazji 500-lecia urodzin Marcina Lutra;Jedność przed nami (Einheit vor uns,rok $)^{50}$.

Z okazji jubileuszu 450-lecia Konfesji Augsburskiej opublikowano oficjalną wypowiedź Jana Pawła II stwierdzającą zgodność Konfesji Augsburskiej

43 UUS, nr 9.

44 Johannes Paul II., Ansprache von Papst Johannes Paul II. an den Rat der Evangelischen Kirche, https://w2.vatican.va/content/john-paul-ii/de/speeches/1980/november/documents/hf_jp_ii_spe_19801117_chiesa-evangelica.html (17.02.2017).

45 Tekst niem.: Dokumente wachsender Übereinstimmung, Hrsg. H. Meyer, u.a., Bd. 1, 271295, Paderborn 1983 (dalej: DWÜ I), Bd. 2, Paderborn 1992 (dalej: DWÜ II). Tekst pol.: Bliżej wspólnoty. Katolicy i luteranie w dialogu 1965-2000, red. i tłum. K. Karski, S.C. Napiórkowski, Lublin 2003, s. 165-195.

46 Tekst niem.: DWÜ I, s. 296-322. Tekst pol.: Bliżej wspólnoty, dz. cyt., s. 197-228.

47 Tekst niem.: DWÜ I, s. 323-328. Tekst pol.: Bliżej wspólnoty, dz. cyt., s. 229-236.

48 Tekst niem.: DWÜ I, s. 329-357. Tekst pol.: Bliżej wspólnoty, dz. cyt., s. 237-271.

49 Tekst niem.: DWÜ II, s. 444-451. Tekst pol.: Bliżej wspólnoty, dz. cyt., s. 274-281.

50 Tekst niem.: DWÜ II, s. 451-506. Tekst pol.: Bliżej wspólnoty, dz. cyt., s. 283-345. 
z tym, czego uczy Kościół katolicki w sprawach wiary ${ }^{51}$. Podczas obrad w Rzymie (27.02-03.03.1984) doszło do spotkania członków Rzymskokatolicko-Luterańskiej Komisji do Dialogu Teologicznego z Janem Pawłem II, który pozytywnie ocenił jej dotychczasową pracę, a wypracowane dokumenty nazwał „znaczącymi elementami na drodze do chrześcijańskiej jedności" ${ }^{52}$.

Trzecia faza katolicko-luterańskiego dialogu miała miejsce w całości w okresie pontyfikatu Jana Pawła II (1986-1993). Podjęto w niej problem rozumienia Kościoła i charakteru jego pośrednictwa w Bożym planie zbawienia, gdzie jednym z istotnych zagadnień stała się nauka o usprawiedliwieniu. We wrześniu 1993 roku opublikowano obszerny raport końcowy pt.: Kościół i usprawiedliwienie. Rozumienie Kościoła w świetle nauki o usprawiedliwieniu (Kirche und Rechtfertigung. Das Verständnis der Kirche im Licht der Rechtfertigung) ${ }^{53}$. Ostatnim dokumentem trzeciej fazy dialogu, poświęconym w całości nauce o usprawiedliwieniu, jest Wspólna deklaracja $w$ sprawie nauki o usprawiedliwieniu ${ }^{54}$ podpisana uroczyście 31 października 1999 roku w Augsburgu przez ówczesnego przewodniczącego Papieskiej Rady dla Popierania Jedności Chrześcijan, kard. Edwarda I. Cassidy'ego i sekretarza tejże rady, bp. Waltera Kaspera, a ze strony luterańskiej przez prezydenta Światowej Federacji Luterańskiej, bp. Christiana Krause oraz sekretarza generalnego Światowej Federacji Luterańskiej, ks. Ishmaela Noko. Została ona zaaprobowana przez Jana Pawła II. Ekumeniczne wypowiedzi Jana Pawła II w pewnym sensie pobudzały i wzmacniały prace Rzymskokatolicko-Luterańskiej Komisji Mieszanej nad wspólną deklaracją na temat usprawiedliwienia.

W dniu 9 czerwca 1989 roku Jan Paweł II odwiedził katedrę luterańską w Uppsali w Szwecji. Złożył wówczas wiązankę kwiatów na grobie

51 S.C. Napiórkowski, Dialog, w: Bliżej wspólnoty. Katolicy i luteranie w dialogu 1965-2000, red. i tłum. K. Karski, S.C. Napiórkowski, Lublin 2003, s. 151.

52 S.C. Napiórkowski, Dialog, dz. cyt., s. 161.

53 Tekst niem.: Gemeinsame Römisch-katholische/Evangelisch-lutherische Kommission, Kirche und Rechtfertigung. Das Verständnis der Kirche im Licht der Rechtfertigung, Paderborn-Frankfurt am Main 1994. Tekst pol.: Bliżej wspólnoty, dz. cyt., s. 261-481.

54 Tekst niem.: Gemeinsame Erklärung zur Rechtfertigungslehre, w: Gemeinsame Erklärung zur Rechtfertigungslehre. Ein Kommentar für Ökumenische Forschung, Straßburg 1997, s. 55-77. Tekst pol.: Blizej wspólnoty, dz. cyt., s. 499-523. 
biskupa luterańskiego, teologa, światowej sławy religioznawcy Natana Söderbloma (zm. 1931), przeciw któremu występował papież Pius XI. Jan Paweł II wezwał wówczas chrześcijan do wzajemnego przebaczenia win. Historyczną wymowę miała wizyta Jana Pawła II w zborze ewangelicko-luterańskim w Rzymie. Papież przytoczył słowa deklaracji Dominus Iesus, podkreślając, że

Kościoły, które nie są w pełnej wspólnocie z Kościołem katolickim, pozostają jednak z nim zjednoczone bardzo ścisłymi więzami, jak sukcesja apostolska i ważna Eucharystia [...]. Dlatego także w tych Kościołach jest obecny i działa Kościół Chrystusowy, chociaż brak im pełnej komunii z Kościołem katolickim, jako że nie uznają katolickiej nauki o prymacie, który Biskup Rzymu posiada obiektywnie z ustanowienia Bożego i sprawuje nad całym Kościołem. Natomiast Wspólnoty kościelne, które nie zachowały prawomocnego episkopatu oraz właściwej i całkowitej rzeczywistości eucharystycznego misterium, nie są Kościołami w ścisłym sensie; jednak ochrzczeni w tych Wspólnotach są przez chrzest wszczepieni w Chrystusa i dlatego są w pewnej wspólnocie, choć niedoskonałej, z Kościołem. [...] Same te Kościoły i odłączone Wspólnoty, choć w naszym przekonaniu podlegają brakom, wcale nie są pozbawione znaczenia i wagi w tajemnicy zbawienia. Duch Chrystusa nie wzbrania się przecież posługiwać nimi jako środkami zbawienia, których moc pochodzi z samej pełni łaski i prawdy, powierzonej Kościołowi.

Brak jedności wśród chrześcijan jest z pewnością raną dla Kościoła: nie w tym sensie, iż Kościół jest pozbawiony jedności, lecz że podział „przeszkadza w pełnym urzeczywistnieniu się jego powszechności w historii" ${ }^{55}$. Papieskie słowa o protestantach i protestantyzmie postrzegać należy w optyce ekumenicznego programu św. Jana Pawła II.

\section{Modlitewne spotkania w Asyżư ${ }^{56}$}

Wydarzeniami bezprecedensowymi w dziejach Kościoła, wpisującymi się w ekumeniczny program (w szerokim rozumieniu) św. Jana Pawła II były modlitewne spotkania przedstawicieli religii świata w Asyżu, zorganizowane z inicjatywy tego Wielkiego Papieża w 1986 i 2002 roku. Ich intencją była modlitwa o pokój. Pokazały one, że współistnienie

55 Kongregacja Nauki Wiary, Deklaracja Dominus Iesus. Ojedyności i powszechności zbawczej Jezusa Chrystusa i Kościoła. Tekst pol. zob. OsRomPol 21 (2000) nr 11/12.

56 Z. Glaeser, Ekumenizm w nauczaniu papieży po Soborze Watykańskim II, dz. cyt., s. 111-114. 
wyznawców różnych religii, ale również swoista „komplementarność” prawd egzystencjalnych (a nie doktrynalnych) głoszonych przez religie stanowi wciąż aktualne wyzwanie do budowania zgody, porozumienia, jedności i pokoju w świecie.

W pierwszym spotkaniu w Asyżu uczestniczyli chrześcijanie z różnych Kościołów i Wspólnot eklezjalnych. Z Kościoła prawosławnego przybyli przedstawiciele Patriarchatu Ekumenicznego w Konstantynopolu, Patriarchatu Grecko-Prawosławnego Antiochii, prawosławnych Kościołów Rosji, Gruzji, Rumunii, Bułgarii, Czechosłowacji i Finlandii. Stare Kościoły Wschodu reprezentowali delegaci: syryjskiego patriarchatu Antiochii i całego Wschodu, katolikosatu ormiańskiego w Eczmiadzynie, katolikosatu armeńskiego Cylicji, Kościoła syryjskiego Indii oraz Asyryjskiego Kościoła Wschodniego. Spośród światowych Wspólnot chrześcijańskich oraz światowych organizacji chrześcijańskich obecni byli przedstawiciele Unii Utrechckiej (starokatolicy), Wspólnoty anglikańskiej, Światowej Federacji Luterańskiej, Światowego Aliansu Kościołów Reformowanych, Światowej Rady Metodystów, Uczniów Chrystusa (Christian Unity of the Christian Church), Światowego Aliansu Baptystów, Ekumenicznej Rady Kościołów, Ekumenicznego Synodu Reformowanego, a także reprezentanci Armii Zbawienia, Menonitów (Mennonite World Conference), Kwakrów (Friends World Committee for Consultation - Religious Society of Friends, Quakers), Chrześcijańskiego Stowarzyszenia Młodych Kobiet (World Young Women 's Christian Association [skrót: YWCA]), Związku Chrześcijańskiej Młodzieży Męskiej (World Young Men's Christian Association [skrót: YMCA]), Unitarian (International Association for Religious Freedom - Unitarian (Church) $)^{57}$.

W spotkaniu w Asyżu reprezentowane były następujące religie niechrześcijańskie: judaizm, buddyzm tybetański (lamaizm), buddyzm therawady, ugrupowania buddyzmu japońskiego, szintoizm, hinduizm, dżinizm, zaratusztrianizm, sikhizm, islam, tradycyjne religie Afryki, tradycyjne religie Ameryki. Swoją obecnością spotkanie asyskie zaszczycił

57 E. Igańska, E. Sakowicz, Ekumeniczne i dialogiczne implikacje modlitewnych spotkańw Asy$\dot{z} u, \mathrm{w}$ : Pontyfikat ekumenicznej nadziei. Z Janem Pawłem II na drogach ekumenizmu, red. Z. Glaeser, Opole 2008, s. 123-139. 
Dalajlama Tybetu. Do Asyżu nie przybyli natomiast buddyści z Indii i Sri Lanki. Nie było również przedstawiciela Chin ${ }^{58}$.

Celem „zwołania Bożego” religii świata (u podstaw decyzji zaproszenia ich wyznawców był - jak zaznaczył Jan Paweł II - impuls dany przez Ducha Świętego) była solidarna modlitwa wszystkich ludzi do Boga o dar pokoju dla świata. Zaproszeni na spotkanie wyznawcy chrześcijańskich wyznań i niechrześcijańskich religii mieli intencję zgodną z Ojcem Świętym: „być razem, aby się modlić o pokój”. W ten sposób ukazali, że modlitwa jest jedyną drogą do wyzwolenia ludzkości od wzajemnej nienawiści i nietolerancji. Spotkanie w Asyżu było też dniem postu jako aktu pokuty i przebłagania Boga ${ }^{59}$.

W czasie spotkania w Asyżu chrześcijanie, chociaż podzieleni, wspólnie świadczyli o Jezusie Chrystusie wobec przedstawicieli religii niechrześcijańskich. Chrześcijaństwo jawiło się jako promotor jedności w świecie doświadczającym licznych wojen, żyjącym w lęku przed eskalacją kolejnych przejawów wrogości między państwami i narodami. Tak, jak Kościół Jezusa Chrystusa jest znakiem jedności rodzaju ludzkiego i niejako sakramentem tej jedności, tak Asyż stał się nadzwyczajnym znakiem jedności całej ludzkości, ludzi różnych kultur, religii, światopoglądów. Papież wskazywał tym samym na swoją posługę jednania i równocześnie na powszechną misję Kościoła, którą jest utwierdzanie ludzi w okazywaniu sobie szacunku i dążeniu do pokoju. Kościół katolicki oraz inne Kościoły, wspólnoty eklezjalne i religie już stanowią jedną społeczność, solidarnie pielgrzymującą ku wieczności ${ }^{60}$.

Drugi Światowy Dzień Modlitwy o Pokój (24.01.2002) miał miejsce w kontekście wydarzeń związanych z atakiem terrorystycznym na World Trade Center w Nowym Jorku (11.09.2001).

Na zaproszenie papieża odpowiedzieli chrześcijanie, żydzi, muzułmanie oraz wyznawcy religii Dalekiego Wschodu i Indii: szintoiści,

58 E. Igańska, E. Sakowicz, Ekumeniczne i dialogiczne implikacje modlitewnych spotkań w Asy$\dot{z} u$, dz. cyt., s. 123-139.

59 E. Sakowicz, „Pokoju nie można osiagnaçć bez modlitwy...” Dziesięciolecie Modlitw o Pokój w Asyżu, ,Jednota" 41 (1997) nr 3, s. 20-21.

60 F. König, H. Waldenfels, Dzień Modlitwy o Pokój w Asyżu, tłum. P. Pachciarek, Warszawa 1989, s. 11. 
konfucjaniści, hinduiści, buddyści oraz przywódcy tradycyjnych religii afrykańskich. W sumie do Asyżu przybyli przedstawiciele 31 wyznań chrześcijańskich i 11 innych religii ${ }^{61}$. Świat usłyszał wówczas słynne papieskie wezwanie: „Nigdy więcej nienawiści! Nigdy więcej wojny! Nigdy więcej terroryzmu! Niech każda religia w imię Boga obdarzy ziemię sprawiedliwością i pokojem, przebaczeniem, życiem i miłością!" ${ }^{2}$.Papież zauważył, że samo spotkanie i gotowość słuchania siebie nawzajem jest znakiem pokoju i służy rozpędzeniu „chmur” podejrzeń i nieporozumień, jakie nagromadziły się nad ludzkością. I skonstatował swoją wypowiedź następująco: „Ciemności nie rozprasza się bronią, ale trzeba w tym celu zapalić źródło światła". Wezwał też do przezwyciężania wrogości, a także do głębszego poznania Boga, który jest źródłem dobra i pokoju, szacunku i harmonii między ludźmi i narodami. Jeszcze raz przypomniał o tym, że modlitwa w Asyżu nie prowadzi do synkretyzmu czy relatywizmu religijnego, bowiem „modlitwy mają ten sam cel, jednakowa jest ich intencja, każdy jednak będzie się modlić zgodnie z własną tradycją" ${ }^{33}$.

Spotkania w Asyżu pokazały, że współistnienie ludzi wiary religijnej stanowi wyzwanie do budowania przez nich zgody, harmonii, porozumienia i jedności w świecie. Były także wyrazem wspólnej troski chrześcijan o zachowanie pokoju, który jest darem Boga i okazją do modlitwy z wyznawcami innych religii. Odbiły się one szerokim echem w całym świecie, owocując lepszym wzajemnym poznaniem się i większym zrozumieniem wewnątrzchrześcijańskim i międzyreligijnym.

\section{Podsumowanie}

Ekumeniczny program św. Jana Pawła II był daleki od utartych schematów. Papieskie wypowiedzi i ekumeniczne działania, dalekie

${ }_{61}$ M. Perfuński, Religie wołają o pokój. Dzień modlitw w Asyżu, „Wiadomości KAI” (2002) nr 5/514, s. 3. Szczegółowy spis uczestników Dnia Modlitw o Pokój w Asyżu w 2002 r. zob. w: Uczestnicy dnia modlitw o pokój, OsRomPol 23 (2002) nr 3, s. 13.

62 Budowanie pokoju zadaniem wszystkich. Przemówienie Papieża Jana Pawła II, OsRomPol 23 (2002) nr 3, s. 18.

${ }^{63}$ Dzień ważny dla świata. Przemówienie powitalne papieża Jana Pawła II, OsRomPol 23 (2002) nr 3, s. 15. 
od stereotypów, cechował styl osobistych głębokich i trafnych przemyśleń, ukazujących wyraźny kierunek drogi ku zjednoczeniu chrześcijan oraz ku jedności całego rodzaju ludzkiego. Trzeba było niezwykłej otwartości na działanie Ducha Świętego oraz odwagi i energii, aby temu zadaniu sprostać. Posługa jednania to jeden z integralnych elementów ludzkiego życia oraz realizacji chrześcijańskiego posłannictwa wobec świata. Człowiek niepojednany, niepojednane narody i Kościoły są zgorszeniem ${ }^{64}$, a czasem nawet zagrożeniem dla świata ${ }^{65}$.

Jan Paweł II wielokrotnie podkreślał, że ekumenizm stanowi jedno z priorytetowych zadań jego pontyfikatu ${ }^{66}$. André Frossard bardzo celnie skonstatował ekumeniczną postawę Jana Pawła II:

Jan Paweł I dał nam Jana Pawła II, który w naszych oczach jest od pierwszego dnia papieżem jedności. Jedności odnalezionej czy jedności na drodze do odnalezienia, po okresie, w którym czuło się, jak widzialna architektura Kościoła chwieje się i pod niewidocznym parciem wewnętrznym, zwielokrotnionym przez potężny huragan historycznej przemiany, nie oszczędzającej w świecie żadnej instytucji, żadnego systemu wartości. Myślę naprawdę, że groziło nam, iż niedługo będziemy mieli tyle Kościołów, ile kontynentów czy intelektualnych kapliczek. Napływ ludów, zgromadzonych przez Jana Pawła II, wzmocnił budowlę i jej jedność odradza się od wewnątrz ${ }^{67}$.

Ekumeniczny program św. Jana Pawła II wyrastał z jego eklezjologii i eschatologii. Zakorzeniony był w przekonaniu o konieczności angażowania się następcy Piotra w działania na rzecz światowego pokoju i jedności. Nic więc dziwnego, że od pierwszych dni swego pontyfikatu, bezgranicznie włączył się w posługiwanie na rzecz jedności Chrystusowego Kościoła i świata. Niezłomną wiarą oraz płynącą z niej „ekumeniczną nadzieją" naznaczone są jego słowa, które wybrzmiały w kontekście apostolskiej podróży do Irlandii (29.09.1979):

64 Por. DE, nr 1.

65 Zob. A. Nossol, Jana Pawła II pontyfikat ekumenicznej nadziei, w: Pontyfikat ekumenicznej nadziei. Z Janem Pawłem II na drogach ekumenizmu, red. Z. Glaeser, Opole 2008, s. 9.

66 Por. G. Caprile, Panorama ecumenico del 1979, „La Civilta Cattolica” (1980) nr 3110, S. 167.

67 A. Frossard, „Nie lękajcie się” - rozmowy z Janem Pawłem II, Kraków 1983, s. 197. 
Szlak będzie wprawdzie uciążliwy, ale, podobnie jak na drodze do Emaus, sam Pan jest z nami w drodze, zawsze tak się zachowując, jakby miał iść dalej (Łk 24, 28). On będzie z nami, aż nadejdzie moment tak bardzo wyczekiwany, kiedy to wspólnie będziemy mogli cieszyć się z poznania Go w Pismach św. i przy łamaniu chleba ${ }^{68}$.

Nie ma więc wątpliwości co do tego, że celem ekumenicznego programu św. Jana Pawła II było wspólne spotkanie wszystkich chrześcijan przy jednym eucharystycznym stole, a co za tym idzie większe uwiarygodnienie chrześcijańskiej misji wobec świata i spotęgowanie jej skuteczności.

\section{Bibliografia}

Barberini G., I problemi del mondo nei discorsi e messaggi di Giovanni Paolo II 16 ottobre 1978-15 ottobre 1979, Rimini 1979.

Celebrazione Eucaristica. Prima domenica di Quaresima. "Giornata del perdono”, Vaticano 2000.

Chlebowski T.J., Jedność - zadany dar Ducha Świętego, „Biuletyn Ekumeniczny” 131/132 (2004) 3/4, s. 58-66.

Dokumente wachsender Übereinstimmung, Hrsg. H. Meyer, u.a., Bd. 1, Paderborn 1983.

Dokumente wachsender Übereinstimmung, Hrsg. H. Meyer, u.a., Bd. 2, Paderborn 1992.

Frossard A., „Nie lękajcie się” - rozmowy z Janem Pawłem II, Kraków 1983.

Gemeinsame Römisch-katholische-Evangelisch-lutherische Kommission, Kirche und Rechtfertigung. Das Verständnis der Kirche im Licht der Rechtfertigung, PaderbornFrankfurt am Main 1994.

Gemeinsame Römisch-katholische-Evangelisch-lutherische Kommission, Gemeinsame Erklärung zur Rechtfertigungslehre, w: Gemeinsame Erklärung zur Rechtfertigungslehre. Ein Kommentar für Ökumenische Forschung, Straßburg 1997, s. 55-77.

Glaeser Z., Droga dialogu - droga pojednania, w: Pojednanie narodów i Kościołów. Materiały sympozjum poświęconego problematyce II Europejskiego Zgromadzenia Ekumenicznego Graz '97, red. P. Jaskóła, Opole 1997, s. 117-126.

Glaeser Z., Ekumenizm w nauczaniu papieży po Soborze Watykańskim II, Kamień Śląski Opole 2017.

Glaeser Z., Enzyklika „Ut unum sint” als Ausdruck der Verantwortung der Römisch-katholischen Kirche für die Versöhnung unter den Christen, w: Ökumenische Verantwortung der Kirchen am Beispiel der Polens und der Schweiz, Hrsg. P. Jaskóła, Opole 1997, s. 61-76.

Glaeser Z., W jednym Duchu jeden Kościót, Opole 1996.

Glaeser Z., Wprowadzenie, w: Pontyfikat ekumenicznej nadziei. Z Janem Pawtem II na drogach ekumenizmu, red. Z. Glaeser, Opole 2008, s. 7-8.

68 G. Barberini, I problemi del mondo nei discorsi e messaggi di Giovanni Paolo II 16 ottobre 1978-15 ottobre 1979, Rimini 1979, s. 2042. 
Glaeser Z., Zadania Kościołów w kształtowaniu europejskiej jedności, w: Pojednanie. Ekumeniczne wyzwania Grazu '97, red. Z. Glaeser, P. Jaskóła, Opole 1998, s. 53-65.

Igańska E., Sakowicz E., Ekumeniczne i dialogiczne implikacje modlitewnych spotkań w Asyzu, w: Pontyfikat ekumenicznej nadziei. Z Janem Pawłem II na drogach ekumenizmu, red. Z. Glaeser, Opole 2008, s. 123-139.

Jan Paweł II, Adhortacja apostolska Ecclesia in Europa, AAS 95 (2003), s. 649-719. Tekst pol.: http://www.opoka.org.pl/biblioteka/W/WP/jan_pawel_ii/adhortacje/ europa_28062003.html (12.05.2017).

Jan Paweł II, Encyklika Redemptor hominis, AAS 71 (1971), s. 257-324. Tekst. pol.: Encykliki Ojca Świętego Jana Pawła II, t. 2, Kraków 1996, s. 5-76.

Jan Paweł II, Encyklika Slavorum Apostoli, AAS 77 (1985), s. 779-813. Tekst pol.: http://www.opoka.org.pl/biblioteka/W/WP/jan_pawel_ii/encykliki/slavorum.html (16.04.2017).

Jan Paweł II, Encyklika Ut unum sint, AAS 87(1995), s. 921-982. Tekst pol. zob. OsRomPol 16 (1995) nr 6, s. 4-31.

Jan Paweł II, List apostolski Egregiae virtutis, AAS 73 (1981), 258-262. Tekst pol.: http://www.cyrylimetody.marianie.pl/egregiae.htm (19.05.2017).

Jan Paweł II, List apostolski Euntes in mundum, AAS 80 (1988), s. 935-956. Tekst pol.: http://franciszkanska3.pl/janpawel2/nauczanie/listy-apostolskie/euntes-in-mundum-universum (12.04.2017).

Jan Paweł II, List apostolski Novo millennio ineunte, AAS 93 (2001), s. 266-309. Tekst pol.: http://www.opoka.org.pl/biblioteka/W/WP/jan_pawel_ii/listy/novo_millenio_06012001.html (12.05.2017).

Jan Paweł II, List apostolski Orientale lumen, AAS 87 (1995), s. 745-774. Tekst. pol. zob. OsRomPol 16 (1995) nr 6, s. 32-44.

Jan Paweł II, List z okazji pięćsetlecia urodzin Marcina Lutra, w: Ut unum. Dokumenty Kościoła katolickiego na temat ekumenizmu 1982-1998, red. S.C. Napiórkowski, K. Leśniewski, J. Leśniewska, Lublin 2000, s. 334-335.

Jan Paweł II, Wszyscy jesteśmy objęci łaską Pana naszego Jezusa Chrystusa. Przemówienie w zborze ewangelicko-luterańskim w Rzymie, w: Ut unum. Dokumenty Kościoła katolickiego na temat ekumenizmu 1982-1998, red. S.C. Napiórkowski, K. Leśniewski, J. Leśniewska, Lublin 2000, s. 484-485.

Kijas Z., Ekumenizm, w: Jan Pawet II. Encyklopedia dialogu i ekumenizmu, red. E. Sakowicz, Radom 2006, s. 163-199.

Kongregacja Nauki Wiary, Deklaracja Dominus Iesus. o jedyności i powszechności zbawczej Jezusa Chrystusa i Kościoła, OsRomPol 21 (2000) nr 11/12, s. 42-51.

König F., Waldenfels H., Dzień Modlitwy o Pokój w Asyżu, tłum. P. Pachciarek, Warszawa 1989.

Metz J.B., Czy Kościół potrzebuje nowej reformacji? Odpowiedź katolika, Poznań-Warszawa 1970, s. 272-279 (Concilium. Międzynarodowy Przegląd Teologiczny, 1/5).

Napiórkowski S.C., Dialog, w: Bliżej wspólnoty. Katolicy i luteranie w dialogu 1965-2000, red. i tłum. K. Karski, S.C. Napiórkowski, Lublin 2003, s. 71-164. 
Nossol A., Jana Pawła II pontyfikat ekumenicznej nadziei, w: Pontyfikat ekumenicznej nadziei. Z Janem Pawtem II na drogach ekumenizmu, red. Z. Glaeser, Opole 2008, s. 9-17.

Papieska Rada dla Popierania Jedności Chrześcijan, Dyrektorium $w$ sprawie realizacji zasad i norm dotyczacych ekumenizmu, tłum. L. Balter, „Communio” 80 (1994) nr 2, s. 3-93. Johannes Paul II., Ansprache von Papst Johannes Paul II. an den Rat der Evangelischen Kirche, https://w2.vatican.va/content/john-paul-ii/de/speeches/1980/november/documents/ hf_jp_ii_spe_19801117_chiesa-evangelica.html (17.02.2017).

Pawłowski S., Ekumeniczne dokumenty i inicjatywy Jana Pawła II oraz ich istotne przesłanie, w: Pontyfikat ekumenicznej nadziei. Z Janem Pawłem II na drogach ekumenizmu, red. Z. Glaeser, Opole 2008, s. 173-183.

Por. Jan Paweł II, List apostolski Tertio millennio adveniente, AAS 87 (1995), s. 5-45. Tekst. pol. zob. OsRomPol 15 (1994) nr 12, s. 4-22.

Ratzinger J., Kościót wspólnota, Lublin 1993.

Rzymskokatolicko-Luterańska Komisja do Dialogu Teologicznego, Drogi do wspólnoty, w: Bliżej wspólnoty. Katolicy i luteranie w dialogu 1965-2000, red. i tłum. K. Karski, S.C. Napiórkowski, Lublin 2003, s. 197-228.

Rzymskokatolicko-Luterańska Komisja do Dialogu Teologicznego, Jedność przed nami, w: Bliżej wspólnoty. Katolicy i luteranie w dialogu 1965-2000, red. i tłum. K. Karski, S.C. Napiórkowski, Lublin 2003, s. 283-345.

Rzymskokatolicko-Luterańska Komisja do Dialogu Teologicznego, Kościół i usprawiedliwienie. Rozumienie Kościoła w świetle nauki o usprawiedliwieniu, w: Bliżej wspólnoty. Katolicy i luteranie $w$ dialogu 1965-2000, red. i tłum. K. Karski, S.C. Napiórkowski, Lublin 2003, s. 261-481.

Rzymskokatolicko-Luterańska Komisja do Dialogu Teologicznego, Marcin Luter świadek Jezusa Chrystusa, w: Bliżej wspólnoty. Katolicy i luteranie w dialogu 1965-2000, red. i tłum. K. Karski, S.C. Napiórkowski, Lublin 2003, s. 274-281.

Rzymskokatolicko-Luterańska Komisja do Dialogu Teologicznego, Urząd duchowny w Kościele, w: Bliżej wspólnoty. Katolicy i luteranie w dialogu 1965-2000, red. i tłum. K. Karski, S.C. Napiórkowski, Lublin 2003, s. 237-271.

Rzymskokatolicko-Luterańska Komisja do Dialogu Teologicznego, Wieczerza Pańska, w: Bliżej wspólnoty. Katolicy i luteranie w dialogu 1965-2000, red. i tłum. K. Karski, S.C. Napiórkowski, Lublin 2003, s. 165-195.

Rzymskokatolicko-Luterańska Komisja do Dialogu Teologicznego, Wspólna deklaracja w sprawie nauki o usprawiedliwieniu, https://papiez.wiara.pl/doc/477995.Wspolna-deklaracja-w-sprawie-nauki-o-usprawiedliwieniu (12.12.2019).

Rzymskokatolicko-Luterańska Komisja do Dialogu Teologicznego, Wspólna deklaracja w sprawie nauki o usprawiedliwieniu, w: Bliżej wspólnoty. Katolicy i luteranie w dialogu 1965-2000, red. i tłum. K. Karski, S.C. Napiórkowski, Lublin 2003, s. 499-523.

Rzymskokatolicko-Luterańska Komisja do Dialogu Teologicznego, Wszyscy pod jednym Chrystusem, w: Bliżej wspólnoty. Katolicy i luteranie w dialogu 1965-2000, red. i tłum. K. Karski, S.C. Napiórkowski, Lublin 2003, s. 229-236.

Sakowicz E., ,Pokoju nie można osiagnać bez modlitwy...”. Dziesięciolecie Modlitw o Pokój w Asyżu, ,Jednota” 41 (1997) nr 3, s. 20-21. 
Sakowicz E., Jan Paweł II wobec protestantów i protestantyzmu, „Egzorcysta” (2017) nr 10/62, s. 55-60.

Sobór Watykański II, Dekret o ekumenizmie „Unitatis redintegratio”, w: Sobór Watykański II, Konstytucje. Dekrety. Deklaracje, Poznań 2002, s. 193-208.

Starczewski K., Ekumenizm w nauczaniu papieży. Od Jana XXIII do Benedykta XVI, Kielce 2018.

Weigel G., Świadek nadziei, Kraków 2000. 